\title{
CLUSTERING ARTIKEL BERITA BERBAHASA INDONESIA MENGGUNAKAN UNSUPERVISED FEATURE SELECTION
}

\author{
Catur tyas surya wigati \\ 175110012 \\ Universitas Mitra Indonesia, Tehnnik informatika \\ Caturtyassuryawigati.student@umitra.ac.id
}

\begin{abstract}
ABSTRAK
Meningkatnya penggunaan internet telah memicu pertumbuhan dan pertukaran informasi menjadi jauh lebihpesat dibandingkan era sebelumnya.Volume berita elektronik berbahasa Indonesia semakin bertambah besardan menyimpan informasi yang berharga di dalamnya.Pengelompokkan berita berbahasa Indonesia merupakansalah satu solusi yang dapat digunakan untuk mempermudah mencerna informasi penting yang ada didalamnya.Clustering dapat digunakan untuk membantu menganalisis berita dengan mengelompokkan secaraotomatis berita yang memiliki kesamaan. Pada text clustering terdapat suatu permasalahan yaitu adanya fitur fitur yang berdimensi tinggi. Diperlukan metode Feature selection untuk mengurangi dimensi fitur ini. Featureselection memiliki kemampuan mengurangi dimensionalitas suatu data sehingga dapat meningkatkanperformansi clustering. Ada beberapa pendekatan sebagai teknik dari implementasi feature selection, salahsatunya adalah filter based feature selection. Pada penelitian ini, dilakukan analisis perbandingan metodefeature selection antara Term contribution dan Document Frequency. Metodemetode feature selection tersebutditerapkan secara filter feature selection. Pada akhir pengujian, dapat dibuktikan bahwa metode Termcontribution lebih baik daripada Document Frequency karena memperhitungkan frekuensi kemunculan termpada suatu dokumen dan jumlah dokumen yang dimiliki term tersebut, sehingga term yang terpilih adalah termyang khas atau bersifat diskriminator. Hal ini dapat meningkatkan performansi clustering dokumen berdasarkanprecision dan entropy.
\end{abstract}

Kata Kunci : clustering, filter feature selection, Term contribution, Document Frequency 


\section{PENDAHULUAN}

Pesatnya pengunaan dan adopsi Internet telah memacu pertumbuhan dan pertukaran informasi yang sangatpesat dibandingkan era sebelumnya.Sebagai akibatnya, jumlah informasi terus meningkat secara exponensial,lebih dari 550 triliun dokumen saat ini.Sebanyak 7.3 juta Internet page baru tiap hari nya.Walau perkembanganini memungkinan informasi untuk di akses penguna dengan mudah, jumlah yang terkendalikan ini telah menimbulkan isu dan tantangan yang besar [1].

Demikian pula halnya dengan berita elektronik berbahasa Indonesia yang volumenya semakin bertambahbesar.Berita yang disampaikan melalui media elektronik ini tentu merupakan sumber informasi yang berharga.Oleh karena itu dibutuhkan sebuah metode khusus untuk dapat mengelompokkan berita - berita tersebutsehingga dapat mempermudah pengambilan informasi penting yang ada di dalamnya.Clustering dokumen teksadalah salah satu operasi pada text mining untuk mengelompokkan dokumen yang memiliki kesamaan isi.Clustering dapat diaplikasikan untuk menemukan keterkaitan antar berita[15]. Clustering dapat digunakan untuk membantu menganalisis berita dengan mengelompokkan secara otomatis berita yang memiliki kesamaan.Pada clustering teks terdapat suatu permasalahan yaitu adanya fitur - fitur yang berdimensi tinggi.Hal inibisa disebabkan karena adanya data yang tidak relevan dan redundan. Kerja dari Clustering tidak akan optimalapabila di dalamnya terdapat fitur yang tidak relevan dan redundan. Oleh karena itu diperlukan metode untukmengurangi dimensi fitur ini. Dalam hal ini ada 2 metode yang sering digunakan, yaitu feature extraction danfeature selection.

Feature extraction adalah proses mengekstrak fitur baru dari fitur asli melalui pemetaan fungsional.Sedangkan feature selection adalah sebuah proses pemilihan subset fitur dari fitur asli[8]. Kelebihan featureselection dibandingkan dengan Feature extraction adalah pada seleksi fitur memberikan pemahaman yang lebihbaik mengenai data sedangkan Feature extraction tidak demikian.Berdasarkan ada atau tidaknya informasi label, feature selection dapat dibedakan menjadi 2 jenis yaitusupervised feature selection dan unsupervised feature selection. Pada supervised feature selection dibutuhkanlabel kelas sedangkan pada unsupervised feature selection tidak. Metode feature selection telah banyakdiaplikasikan pada classification teks tetapi jarang dilakukan pada clustering teks.

Penelitian ini bertujuan untuk mengimplementasikan unsupervised feature selection yaitu DocumentFrequency (DF) dan Term Contribution (TC) pada clustering berita berbahasa Indonesia, Dua macam analisa

yang dilkukan adalah sebagai berikut :

1. Analisis pengaruh metode unsupervised feature selection pada performansi clustering teks berdasarkanentropy dan precision Measure

2. Analisis perbandingan Term Contribution (TC) dengan Document Frequency (DF) pada clustering teksberdasarkan entropy dan precision Measure. 


\section{TINJAUAN PUSTAKA}

\subsection{Text Mining}

Text mining sudah banyak didefinisikan oleh ahli riset dan praktisi $[1,2,3,6]$. Text mining memiliki definisimenambang data yang berupa teks di mana sumber data biasanya didapatkan dari dokumen, dan tujuannyaadalah mencari kata - kata yang dapat mewakili isi dari dokumen sehingga dapat dilakukan analisaketerhubungan antar dokumen.Sistem text mining terdiri dari komponen text preprocessing, feature selection, dan komponen data mining.Komponen text preprocessing berfungsi untuk mengubah data tekstual yang tidak terstruktur seperti dokumen,

kedalam data terstruktur dan disimpan ke dalam basis data. Feature selection akan memilih kata yang tepat danberpengaruh pada proses klasifikasi. Komponen terakhir akan menjalankan teknik data mining pada output darikomponen sebelumnya.

\subsection{Text Prepocessing}

Teks yang akan dilakukan proses text mining, pada umumnya memiliki beberapa karakteristik diantaranyaadalah memiliki dimensi yang tinggi, terdapat noise pada data, dan terdapat struktur teks yang tidak baik[1].Cara yang digunakan dalam mempelajari suatu data teks, adalah dengan terlebih dahulu menentukan fiturfituryang mewakili setiap kata untuk setiap fitur yang ada pada dokumen.Sebelum menentukan fitur - fitur yang mewakili, diperlukan tahap preprocessing yang dilakukan secaraumum dalam text mining pada dokumen, yaitu case folding, tokenizing, filtering, stemming, tagging dananalyzing.Case folding adalah mengubah semua huruf dalam dokumen menjadi huruf kecil.Hanya huruf ' $a$ ' sampaidengan ' $z$ ' yang diterima.Karakter selain huruf dihilangkan dan dianggap delimiter.Tahap tokenizing / parsing adalah tahap pemotongan string input berdasarkan tiap kata yang menyusunnya.Tahap filtering adalah tahap mengambil kata - kata penting dari hasil token.Bisa menggunakan algoritmastoplist (membuang kata yang kurang penting) atau wordlist (menyimpan kata penting).Stoplist / stopwordadalah kata-kata yang tidak deskriptif yang dapat dibuang dalam pendekatan bag-of-words. Contoh stopwordsadalah "yang", "dan", "di", "dari” dan seterusnya.

Tahap stemming adalah tahap mencari root kata dari tiap kata hasil filtering. Pada tahap ini dilakukan prosespengembalian berbagai bentukan kata ke dalam suatu representasi yang sama. Tahap ini kebanyakan dipakaiuntuk teks berbahasa inggris dan lebih sulit diterapkan pada teks berbahasa Indonesia. Hal ini dikarenakanbahasa Indonesia tidak memiliki rumus bentuk baku yang permanen.

\subsection{Feature Selection}

Terdapat dua pendekatan feature selection yang digunakan pada machine learning, yaitu filtering danwrapper[2].

2.3.1. Pendekatan Feature Selection

2.3.1.1. Filter Feature Selection

Salah satu pendekatan Feature Selection dalam pemilihan feature adalah filter feature

Selection. Pemilihanfeature dengan filter model ini lebih murah dalam komputasi karena tidak melibatkan induksi algoritma dalamprosesnya[18]. Oleh karena itu, 
penerapan pendekatan filter ini cocok untuk data yang berdimensi tinggi sepertitext mining.Gambar 1 Filter Based Feature Selection

2.3.1.2. Wrapper Feature Selection

Pada pendekatan wrapper, pemilihan feature subset menggunakan fungsi evaluasi berdasarkan algoritmalearning yang sama yang akan digunakan untuk proses clustering. Dalam algoritma pemilihan feature, terdapatdua komponen utama yaitu pembangkitan prosedur dan fungsi evaluasi. Komponen pertama dilakukan setelahfeature space terbentuk, dilakukan pencarian prosedur yang menghasilkan subset dari fitur untuk dievaluasi.Komponen kedua melakukan fungsi evaluasi sebagai ukuran pemilihan subset.Ide dasar dari pendekatan wrapper ini bahwa setiap fitur dari feature subset dievaluasi oleh inductivelearning algorithm yang dibungkus didalam prosedur feature selection sebagai "black box".

\subsubsection{Metode Unsupervised Feature Selection}

\subsubsection{Document Frequency}

Document Frequency adalah jumlah dokumen yang mengandung suatu term tertentu. Tiap term akandihitung nilai Document Frequency-nya (DF). Lalu term tersebut diseleksi berdasarkan jumlah nilai DF. Jikanilai DF berada di bawah threshold yang telah ditentukan, maka term tersebut akan dibuang. Asumsi awalnya adalah bahwa term yang lebih jarang muncul tidak memiliki pengaruh yang besar dalamproses pengelompokkan dokumen. Pembuangan term yang jarang ini dapat mengurangi dimensi fitur yang besarpada text mining.Perbaikan dalam pengelompokkan dokumen ini juga dapat terjadi jika term yang dibuang tersebut jugamerupakan noise term. Document Frequency merupakan metode future selection yang paling sederhana denganwaktu komputasi yang rendah [17].Ilustrasi dari metode Document Frequency ini adalah sebagai berikut.Jika terdapat data berjumlah 5000dokumen, dan jumlah dokumen yang mengandung term "teknologi" adalah 150 dokumen. Maka nilaiDF(teknologi) adalah 150.

\subsubsection{TERM CONTRIBUTION}

Term Contribution diperkenalkan pertama kali oleh Tao Liu dan kawan-kawannya pada tahun 2003 [9]. Idedasarnya adalah bahwa hasil dari clustering teks sangat bergantung pada kesamaan dokumen.Jadi, kontribusidari sebuah term dapat dipandang sebagai kontribusinya terhadap kesamaan dokumen. Kesamaan antar dokumendi dan di dapat dihitung menggunakan dot product :

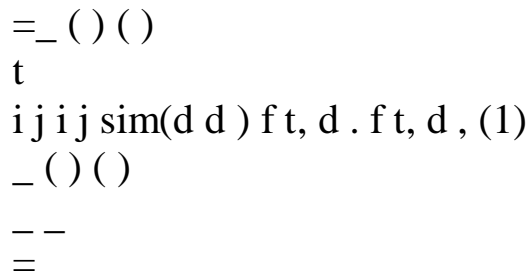

i j i j

i j TCt ft d t d

,

( ) , , (2)

Di mana, $f(t, d)$ merupakan bobot $t f *$ idf dari term $t$ di dokumen d.Jadi kontribusi dari sebuah term pada dataset, sama dengan kontribusinya secara keseluruhan 
padakesamaan dokumen. Persamaannya yaitu :Metode "TC" digunakan untuk menghitung nilai tf*idf tiap term dengan cara menggunakan TermFrequency (TF) dan mengalikannya dengan bobot Inverse Document Frequency (IDF) dari term tersebut, danakhirnya menormalisasikan panjang dokumen. Persamaannya yaitu :

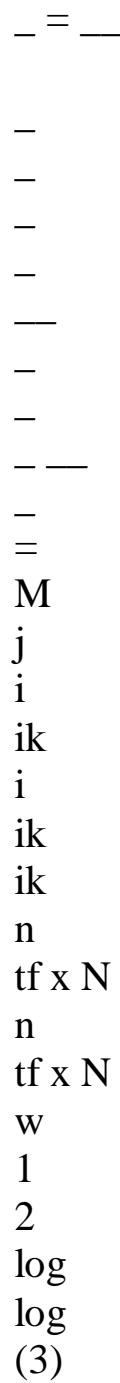

Jika bobot semua term sama, maka nilai $\mathrm{f}(\mathrm{t}, \mathrm{d})=1$ ketika term $\mathrm{t}$ muncul di dokumen $\mathrm{d}$. Sehingga nilai TC(t)

bisa ditulis dalam persamaan berikut:

$\mathrm{TC}(\mathrm{t})=\mathrm{DF}(\mathrm{t})(\mathrm{DF}(\mathrm{t})-1)(4)$

2.3.2.3. Term Frequency (Tf)

Term Frequency merupakan salah satu metode untuk menghitung bobot tiap term dalam text. Dalam metodeini, tiap term diasumsikan memiliki nilai kepentingan yang sebanding dengan jumlah kemunculan term tersebutpada text [10]. Bobot sebuah term t pada sebuah text d dirumuskan dalam persamaan berikut:

$\mathrm{W}(\mathrm{d}, \mathrm{t})=\mathrm{TF}(\mathrm{d}, \mathrm{t})(5)$

Dimana TF $(\mathrm{d}, \mathrm{t})$ adalah term frequency dari term $\mathrm{t}$ di text $\mathrm{d}$. Term frequency dapat memperbaiki nilai recallpada information retrieval, tetapi tidak selalu memperbaiki 
nilai precision. Hal ini disebabkan term yangfrequent cenderung muncul di banyak text, sehingga term - term tersebut memiliki kekuatan diskriminatif /keunikan yang kecil. Untuk memperbaiki permasalahan ini, term dengan nilai frekuensi yang tinggi sebaiknyadibuang dari set term. Menemukan threshold yang optimal merupakan fokus dari metode iniSeminar Nasional Informatika 2010 (semnasIF 2010) ISSN: 1979-2328

2.3.2.4. Inverse Document Frequency (Idf)Jika Term Frequency fokus pada kemunculan term dalam sebuah text, Inverse Document Frequency (IDF)fokus pada kemunculan term pada keseluruhan koleksi text. Pada IDF, term yang jarang muncul padakeseluruhan koleksi term dinilai lebih berharga. Nilai kepentingan tiap term diasumsikan berbanding terbalikdengan jumlah text yang mengandung term tersebut [10]. Nilai IDF sebuah term $t$ dirumuskan dalam persamaan berikut:

$\operatorname{IDF}(\mathrm{t})=\log (\mathrm{N}$ df $(\mathrm{t}))(6)$

Di mana $\mathrm{N}$ adalah total jumlah text / dokumen pada koleksi dan df(t) adalah jumlah dokumen yangmengandung term t. Persamaan ini mengacu pada definisi Salton [11]. IDF dapat memperbaiki nilai precision, karena mengkhususkan fokus pada sebuah term dalam keseluruhan dokumen.Penelitian belakangan ini [11]telah mengkombinasikan TF dan IDF untuk menghitung bobot term dan menunjukkan bahwa gabungankeduanya menghasilkan performansi yang lebih baik. Kombinasi bobot dari sebuah term $t$ pada text ddidefinisikan sebagai berikut:

$\operatorname{TFIDF}(\mathrm{d}, \mathrm{t})=\mathrm{TF}(\mathrm{d}, \mathrm{t}) \quad$ IDF(t) (7)Faktor TF dan IDF dapat berkontribusi untuk memperbaiki nilai recall dan precision [11].

2.4. Clustering

Pesatnya pertambahan jumlah dan keanekaragaman dokumen dapat berdampak besar pada saat pencariansuatu dokumen.Clustering dokumen merupakan tool yang penting pada pengorganisasian dokumen yang efisien[13]. Subactivitas clustering termasuk representasi dokumen, penurunan dimensi, penggunaan cluster algorithmdan evaluasi [1]. Riset di text clustering ini sudah banyak dikerjakan, termasuk oleh $[2,4,5,7,9$, $10,13,16,17]$.Metode clustering tidak memiliki pendefinisian target class, karenanya disebut sebagai juga sebagaiunsupervised learning [12]. Analisis cluster membagi data menjadi beberapa cluster - cluster (kelompok) yangmemiliki arti, berguna atau keduanya. Untuk mendapatkan pengkategorian dari hasil pencarian yang baik, makadapat diterap beberapa algoritma yang ada pada clustering, salah satu diantaranya yaitu Suffix Tree Clustering(STC), K-Means dan algoritma lainnya.Permasalahan mendasar pada clustering dokumen adalah tingginya dimensi data.Beberapa metode untukmengurangi dimensi tersebut telah dilakukan. Ada 2 cara untuk mengurangi dimensi data, yaitu feature selectiondan feature transformation.

2.5. Algortima K-Means

Eksperimen ini menggunakan algoritma yang paling umum digunakan dalam clustering yaitu algoritmaK-Means.Algoritma ini populer karena mudah diimplementasikan dan kompleksitas waktunya linear.

Kelemahannya adalah algoritma ini sensitif terhadap inisialisasi cluster Dasar algoritmanya adalah sebagai berikut:

1) Inisialisasi cluster 
2) Masukkan setiap dokumen ke cluster yang paling cocok berdasarkan ukuran kedekatan dengan centroid.Centroid adalah vektor term yang dianggap sebagai titik tengah cluster.

3) Setelah semua dokumen masuk ke cluster. Hitung ulang centroid cluster berdasarkan dokumen yang berada didalam cluster tersebut.

4) Jika centroid tidak berubah (dengan treshold tertentu) maka stop. Jika tidak, kembali ke langkah 2.Ukuran kedekatan antara dua vector term $\mathrm{t} 1, \mathrm{t} 2$ yang digunakan pada paper ini adalah cosinus sudut antara kedua vektor tersebut

( )

12

12

12 .

$\mathrm{t} \mathrm{t}$

$\mathrm{t} t$

$\operatorname{Cos} \mathrm{t} t=(8)$

2.6. Evaluation Measures

Untuk mengevaluasi apakah hasil clustering yang diperoleh baik atau tidak maka perlu dilakukan validasi clustering yang bertujuan untuk membandingkan hasil clustering dengan informasi class sesungguhnya dan membandingkan antara dua hasil clustering untuk mengetahui hasil mana yang lebih baik [14].

2.6.1. Precision

Precision adalah rasio penempatan cluster yang benar oleh sistem dibagi keseluruhan penempatan olehsistem. Semakin besar nilai Precision, maka semakin bagus cluster yang dihasilkan [9]. Rumusnya:

(\{ \}) i i j d label d c

A

ecision $\mathrm{A}=\max ()=$

1

$\operatorname{Pr}()$

(9)

Pr Pr ( )

1

$\mathrm{k}$

G

$\mathrm{k}$

$\mathrm{k}$ ecision $\mathrm{A}$

$\mathrm{N}$

A

ecision _

$=$

$=(10)$

Penjelasan untuk semua notasi diatas : 
- $\mathrm{A}=$ jumlah dokumen yang diklasterkan dalam satu kategori

- $\mathrm{dj}=$ kategori yang diberikan

- $\mathrm{cj}=$ cluster yang dibentuk

- $\mathrm{L}=$ jumlah class

k A =jumlah dokumen yang diklasterkan pada semua kategori

- $\mathrm{N}=$ total jumlah dokumen

2.6.2. Entropy

Entropy mengukur kemurnian dari klaster yang dihasilkan dengan memperhatikan pada kategori yang ada.

Nilai Entropy yang lebih kecil menghasilkan klaster yang lebih bagus kualitasnya [9].

$\{()\}$ i i j

$\mathrm{k}$

jk d label d c

A

$\mathrm{P}==1$

(11)

$--()$

$==$

$=-$

G

$\mathrm{j}$

$\mathrm{jk} \mathrm{jk}$

$\mathrm{G}$

$\mathrm{k}$

$\mathrm{kp} \times \mathrm{p}$

$\mathrm{N}$

A

Entropy

11

$\log$

(12)

Penjelasan untuk semua notasi diatas :

- $\mathrm{A}=$ jumlah dokumen yang diklasterkan dalam satu kategori

- $\mathrm{dj}=$ kategori yang diberikan

- $\mathrm{cj}=$ cluster yang dibentuk

- $\mathrm{L}=$ jumlah class

$\mathrm{k} \mathrm{A}=$ jumlah dokumen yang diklasterkan pada semua kategori

- $\mathrm{N}=$ total jumlah dokumen

- pjk= peluang dokumen kategori $\mathrm{k}$ masuk ke klaster $\mathrm{j}$ 


\section{STUDI KASUS}

\subsection{Analisis Sistem}

Dalam sistem yang akan dikerjakan pada Tugas Akhir ini, masukkan ke sistem adalah artikel berita yangberasal dari website media cetak yang diambil secara offline. Awalnya, artikel tersebut akan dimasukkan ke dalam file dokumen berita berekstensi .txt. Awalnya, dilakukan preproses dokumen untuk mengubah struktur dokumen menjadi data dengan struktur yang sesuai dengan cara melakukan case folding, tokenization, filtering dan stemming-. Setelah preproses berakhir, dilakukan proses Feature Selection. Akan tetapi sebelum proses Feature

Selection dilakukan, perlu dilakukan perhitungan kemunculan term dalam dokumen. Hasil perhitungan inilah yang akan menjadi inputan bagi proses Feature Selection. Kemudian dilakukan clustering menggunakan tools.Kemudian proses klasifikasi pun berakhir dengan perhitungan precision dan entropy sebagai pengukuran performansi yang dihasilkan. Proses ini ditunjukkan pada gambar 2.

Gambar 2. Gambaran proses sistem secara umum

Secara umum, hasil akhir dari system yang dibuat pada Tugas Akhir ini adalah record hasil Feature Selection yang siap untuk diolah ke dalam tools sesuai bagian yang diberi garis putus-putus.

\section{DISKUSI}

Dalam sistem yang dibuat, masukkan ke sistem adalah artikel berita yang berasal dari website media cetak yang diambil secara offline. Awalnya, artikel tersebut akan dimasukkan ke dalam file dokumen berita berekstensi ttxt. Awalnya, dilakukan preproses dokumen untuk mengubah struktur dokumen menjadi data dengan struktur yang sesuai dengan cara melakukan case folding, tokenization, filtering dan stemming-. Setelah preproses berakhir, dilakukan proses Feature Selection. Akan tetapi sebelum proses Feature Selection dilakukan, perlu dilakukan perhitungan kemunculan term dalam dokumen. Hasil perhitungan inilah yang akan menjadi masukan bagi proses Feature Selection. Kemudian dilakukan clustering menggunakan tools.Kemudian proses klasifikasi pun berakhir dengan perhitungan precision dan entropy sebagai pengukuran performansi yang dihasilkan. Dataset yang digunakan yaitu Indonesian TREC-like Corpus yaitu dataset yang berisikan kumpulan artikelartikelyang berasal dari media surat kabar kompas ,dataset ini menggunakan 120 artikeldengan 6 kategori dan 225 artikel dengan 6 kategori.

4.1. Analisis Precision

Dalam hal ini, diukur nilai Precision dengan clustering K-Means terhadap dataset 120 dokumen yang telah dilakukan Feature Selection dengan metode Document Frequency dan Term Contribution. Hal ini ditunjukkan pada gambar 1 pada lampiran. Pada Term Contribution dapat dilihat bahwa, nilai precision cenderung meningkat, mulai dari pembuangan term $60 \%$ hingga $96 \%$, kemudian sedikit menurun ketika term dibuang hingga $96 \%$, dan nilai precision terus 
stabil ketika term dibuang 97\% hingga 99\%. Nilai precision yang semakin meningkat membuktikan bahwa performansi clustering menjadi lebih baik ketika fiturnya dikurangi sebanyak 96\%.Pada Document Frequency, dapat disimpulkan bahwa nilai precision pada Document Frequency, cenderung mengalami peningkatan hingga term dibuang sebesar 94\%, berbeda dengan Term Contribution yang baru menurun stabil ketika term dibuang sebesar $96 \%$. Hal ini berarti jumlah maksimal term yang dapat dibuang Menghitung kemunculan term berdasarkan pembobotan

Feature Selection

Document

Frequency

Term Contribution

Pemilihan

threshold

Klasterisasi dengan

tools Weka

Perhitungan

Precision dan

Entropy

Preproses Dokumen

Proses Stemming

Tokenization /

pemisahan kata

Filtering /

penghilangan token

berdasarkan stopword

Case Folding

untuk meningkatkan performansi clustering, lebih sedikit 2\% jika menggunakan metode Term Contributiondaripada metode Document Frequency. Dari pengujian ini juga dapat dilihat bahwa adanya kedua metode feature selection ini dapat memperbaiki performansi clustering. Karena ketika jumlah term masih $100 \%$ atau tidak dikurangi fiturnya, maka nilai precisionnya lebih rendah jika dibandingkan dengan nilai precision setelah pengurangan term yaitu 4-975, kecuali jika term tersebut dibuang 40\%.Selain itu jika dibandingkan dengan seksama, maka dapat disimpulkan nilai precision Term Contribution rata - rata lebih baik untuk setiap tahap pembuangan term. Hal ini berarti metode Term Contribution lebih baik daripada Document Frequency dalam memperbaiki performansi clustering.Hal ini dapat dihubungkan dengan perbedaan sifat kedua metode tersebut, yaitu bahwa Term Contribution lebih handal daripada Document Frequency, karena Term Contribution memberikan bobot pada sebuah term dengan

mempertimbangkan kontribusi atau peran term tersebut yaitu adanya nilai term frequency dan inverse DocumentFrequency pada setiap pasangan dokumen. Jika term tersebut terjadi di banyak pasangan dokumen, berarti termtersebut memiliki kemiripan atau kesamaan topic.

4.2. Analisis Entropy 
Pada percobaan dengan 120 dokumen ini dapat dilihat bahwa unsupervised feature selection yaitu Document Frequency dan Term Contribution dapat memperbaiki performansi clustering yaitu nilai Entropy. Entropy mengukur kemurnian dari klaster yang dihasilkan dengan memperhatikan pada kategori yang ada.Nilai Entropy yang lebih kecil menghasilkan klaster yang lebih bagus kualitasnya [9].Dalam hal ini, diukur nilai Entropy dengan clustering K-Means terhadap dataset 120 dokumen yang telah dilakukan Feature Selection dengan metode Document Frequency dan Term Contribution. Hal ini ditunjukkan pada gambar 1 pada lampiran. Nilai maksimum entropy pada Document Frequency dan Term Contribution adalah sama yaitu 0.49 ketika term dibuang $40 \%$. Hal ini berarti jumlah term yang dibuang saat itu sama dan menghasilkan performansi clustering yang paling buruk. Dari hasil percobaan ini dapat dilihat bahwa adanya kedua metode feature selection ini dapat memperbaiki performansi clustering. Karena ketika jumlah term masih $100 \%$ atau tidak dikurangi fiturnya, maka nilai entropy-nya lebih tinggi jika dibandingkan dengan nilai entropy setelah pengurangan term yaitu 0.43 , kecuali

jika term tersebut dibuang $40 \%$. Selain itu jika dibandingkan dengan seksama, maka dapat disimpulkan nilai entropy Term Contribution rata - rata lebih baik untuk beberapa tahap pembuangan term.Hal ini berarti metode Term Contribution lebih baik daripada Document Frequency dalam memperbaiki performansi clustering.

\subsection{ANALISIS PERSAMAAN TERM CONTRIBUTION}

Term Contribution melihat pentingnya pengaruh kesamaan dokumen - dokumen yang ada terhadap clustering teks. Jadi, kontribusi atau pengaruh suatu term, dapat dipandang sebagai kontribusi atau pengaruhnya terhadap kesamaan seluruh dokumen yang ada Document Frequency menganggap setiap term memiliki tingkat kepentingan yang sama walaupun terdapat

di berbagai dokumen. Hal ini berarti semakin banyak term tersebut terdapat di dalam dokumen yang berbeda, maka nilainya semakin besar dan memiliki pengaruh yang semakin besar pula pada clustering dokumen Jika diperhatikan dari kedua percobaan sebelumnya, maka dapat diketahui nilai precision dan entropy kedua percobaan di atas sama hingga term dibuang sebanyak $40 \%$. Hal ini terjadi karena kedua metode tersebut membuang term yang sama. Untuk mempermudah proses analisa, maka dilakukan percobaan dengan dataset yang lebih sedikit yaitu berjumlah 4 dokumen dan 621 term. Ketika term dibuang 40\% maka terlihat, term yang dibuang adalah term yang sama yaitu yang memiliki nilai Document Frequency yang kecil. Tabel 1 dan 2 pada lampiran menunjukkan hasil percobaan ini.Pada Term Contribution, suatu term dianggap penting jika term tersebut terjadi di sedikit dokumen dan memiliki frekuensi term yang besar di sebuah dokumen. Dengan cara ini, maka hasil clustering yang dihasilkan akan lebih baik, karena term yang tersisa adalah term yang khas atau bersifat diskriminator. Sedangkan jika nilai term frequency tidak dilihat, atau freuensi kemunculan term dalam sebuah dokumen hanya bersifat Boolean, maka metode TC akan mirip dengan metode DF yaitu hanya memperhatikan jumlah dokumen yang dimiliki term. Oleh karena itu, metode DF adalah bentuk khusus dari metode TC.

Kesimpulan lain, yang dapat diambil adalah bahwa nilai precision dan entropy pada kedua percobaan di atas, memiliki pola yang hampir sama, namun naik turun. 
Artinya, feature selection tidak selalu dapatmemperbaiki kualitas atau performansi clustering. Dapat dilihat pada percobaan pertama, performansi clustering mengalami penurunan pada pembuangan term sebesar $40 \%$. Oleh karena itu perlu dicari titik maksimal di mana feature selection menghasilkan nilai performansi yang terbaik. Pada kedua percobaan di atas, diperoleh hasilbahwa feature selection akan memperoleh hasil terbaik pada pembuangan term 96\% untuk Term Contribution dan 94\% untuk Document Frequency.

\section{KESIMPULAN}

Dari hasil analisis dan pengujian dalam penelitian ini, maka didapatkan kesimpulan :

1. Feature Selection dapat mempengaruhi performansi clustering berdasarkan pengukuran precision dan entropy. Tetapi feature selection tidak selalu dapat memperbaiki kualitas atau performansi clustering, ada beberapa titik di mana feature selection justru dapat mengurangi nilai performansi, oleh karena itu perlu dicari titik maksimal pembuangan term dari data set.

2. Term Contribution dan Document Frequency dapat mengurangi dimensi data serta memperbaiki performansi clustering berdasarkan pengukuran precision dan entropy dengan cara menghilangkan fitur yang tidak relevan, redundant dan noise.

3. Pada Term Contribution, term yang dianggap baik adalah term yang memiliki nilai term frequency yang besar dan terjadi di sedikit dokumen.

4. Pada Document Frequency, term yang dianggap baik adalah term yang terjadi di banyak dokumen.

5. Term Contribution lebih baik daripada Document Frequency yaitu dapat menghasilkan nilai precision dan entropy lebih baik dengan fitur yang lebih sedikit. Hal ini dikarenakan Term Contribution mempertimbangkan frekuensi kemunculan term dan frekuensi dokumen sebuah term, sehingga term yang tetap dipertahankan adalah term yang khas atau bersifat diskriminator, berbeda halnya dengan Document Frequency yang hanya mempertahankan term - term yang bersifat umum.

\section{DAFTAR PUSTAKA}

[1] Adiwijaya, Igg. (2006). Texi Mining dan Knowledge Discovery.Komunitas Data mining Indonesia \&Soft-omputing Indonesia.

[2] Chen Jinxiu, Ji,Tan, Unsupervised Feature Selection for Relation Extraction, National University of Singapore,2005

[3] Dash Manorjan , Liu. Dimensionality Reduction.National University of Singapore. 1997

[4] Dash Manorjan, Liu, Feature Selection for Clustering, PAKDD, 2000.

[5] Devaney, M. \& A. Ram.Efficient feature selection in conceptual clustering. In proceedings of the Fourteenth International Conference on Machine Learning, pages 92-97, 1997. 
[6] Franke J, Gholamreza Nakhaeizadeh, and Ingrid Renz. Text mining: Theoretical Aspects and Applications

[7] Lerman, Kristina. (1999). Document Clustering in Reduced Dimension Vector Space. 